\title{
Enhancing public project implementation in Botswana during the NDP 11 period
}

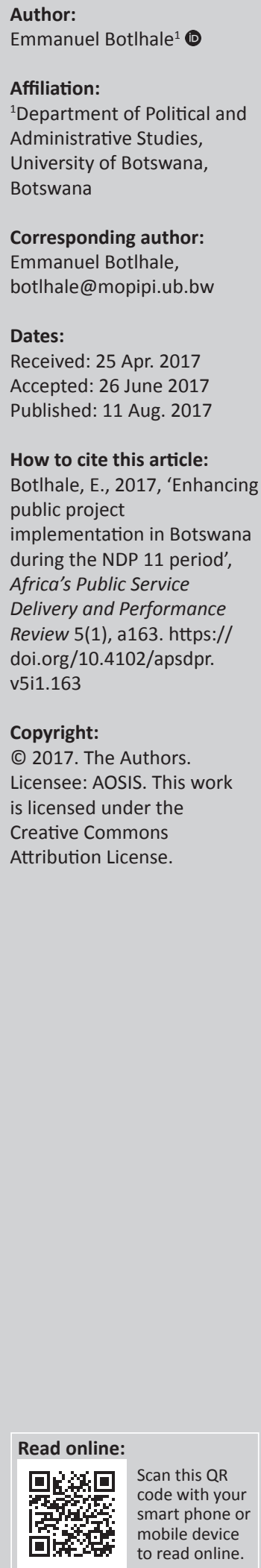

\begin{abstract}
Successful project implementation is critical in development planning. If there is poor project implementation, economic development will be stalled. Generally, public project implementation has a chequered history. This is particularly true in developing countries which are characterised by low levels of project management maturity. The objective of this article is to review public project implementation in Botswana and recommend improvements for the National Development Plan (NDP) 11 period (2017/2018-2022/2023). The article used the survey strategy and adopted the descriptive approach. Data collection sources were mixed, that is, primary and secondary sources. It concluded that public projects are either poorly implemented (i.e. not implemented in accordance with the 'Project Management Triple Constraint' of cost, time and scope) or not implemented at all. Given a constrained revenue envelope post 2008, there is a need for improved project implementation. Amongst others, this calls for professional public project implementation so that NDPs become a reality.
\end{abstract}

\section{Introduction}

Humans have three basic needs to ensure survival, namely food, shelter and clothing (see e.g. Denton 1990). However, the wants of humans are innumerable, so satisfying the wants on the one hand and the needs on the other presents difficulties for governments, given resource scarcity. Scarcity is the inability of resources, whether land, labour, capital and so on, to satisfy human needs and unlimited wants. Because of scarcity, economic agents, be they individuals, households, firms or governments, have to rank their needs and wants in order of preference. Through the scale of preference, pressing (or priority) needs and wants are positioned at the top of the scale so that they are satisfied first subject to the availability of resources. Unlike Moses in the bible (see Exodus 16:35) who had the luxury of summoning manna from heaven when he was on a pilgrimage to the Promised Land, economic agents such as governments do not have such a luxury. Therefore, amongst others, planning is imperative. Planning is a mechanism that allows governments to rank their preferences and design work packages such as projects to implement them. In Botswana, national development planning is actualised through National Development Plans (NDPs). NDPs are mere intentions that can only have a meaning if they are translated into goods and services, for example schools, to improve citizens' lives. To this end, in a foreword to the third NDP, 1970-75, then President Seretse Khama emphasised the centrality of national development planning when he said:

Our commitment to planning springs from the recognition that our resources are limited, and must therefore be carefully allocated. We are in a critical stage in our development. Decisions taken in the current plan period affect the quality of life in Botswana for generations. We must therefore be sure that we understand the choices before us and make the right decisions. (Ministry of Finance and Development Planning 1975:1)

Since attaining independence in September 1966, Botswana has been unremittingly committed to national development planning through the production of NDPs. Starting with Botswana's Transitional Plan for Social and Economic Development prepared in 1965, NDPs have been unfailingly produced. NDPs are national macroeconomic blueprints that contain government strategies planned to be undertaken over the Plan period. To deliver the NDPs, programmes and projects are designed and implemented. The most recent plan was NDP 10, the tenth in a series of NDPs. NDP 11, the draft of which was approved by parliament in December 2016 (Mathambo 2017), commenced operations on 01 April 2017. NDPs are mere intentions that can only have a meaning if they are translated into goods and services, for example schools, hospitals, roads, bridges and so on, to improve the lives of the Batswana. For this to happen, programme and projects implementation is key. Unfortunately, Botswana has a chequered history of project implementation (see e.g. Lucas 2008; Maruapula 2008; Mathambo 2014, 2015; Phatshwe 2014). Then President Ketumile Masire 
publically raised the issue in mid-1995, when he stated that 'there is a growing gap between the establishment of policy and its implementation' and that 'the rapid growth in the formulation of policies have [sic] not been matched by the pace of implementation' (Lucas 2008:10). Masire's successor, Festus Mogae (1998-2008), similarly worried about the issue. This actuated him to recall then Vice President Ian Khama from a 12-month sabbatical leave in August 2000 to oversee public project implementation. He put it concretely saying that he recalled his vice 'so that he could direct and coordinate ministries to ensure efficiency and expeditious implementation of government projects and programmes'(Botswana Press Agency [BOPA] 2000:1). In regard to the recent Plan, NDP 10, a midterm review conducted in 2012 showed that public project implementation is still problematic. As the country is currently implementing NDP 11 and given fiscal strictures post 2008, it is vital that issues of improved public project implementation be brought to the fore of public discourse. This is what this article primarily intends to do.

The article is organised as follows: firstly, it reviews the literature on project implementation. Secondly, it discusses the research methodology. Thirdly, it discusses the institutional framework of public project implementation in Botswana. Fourthly, it discusses project implementation issues in Botswana (field stories). Fifthly, it makes suggestions to improve the regime of public project implementation in Botswana during the NDP 11 period (2017/2018-2022/2023). Finally, it concludes with summarising thoughts.

\section{Literature review on project implementation}

There are five phases in the life of a project: (1) initiation, (2) planning, (3) implementation (sometimes called execution), (4) monitoring and controlling and (5) commissioning and close-out (e.g. see Project Management Institute 2013). For expositional clarity, it is very important to define key operational terms such as implementation. Implementation is defined as a specified set of activities designed to put into practice an activity or programme of known dimensions (National Implementation Research Network 2014). In a related vein, implementation is defined 'as a specified set of activities designed to put into practice an activity or programme of known dimensions' (Fixsen et al. 2005:5). Employing Fixsen et al.'s definition, 'implementation processes are purposeful and are described in sufficient detail such that independent observers can detect the presence and strength of the "specific set of activities" related to implementation' (Fixsen et al. 2005:5). Developing the definition of implementation further, Fixsen et al. argue that regard must be paid to two sets of activities: (1) intervention-level activity and (2) implementation-level activity, and two sets of outcomes: (1) intervention outcomes and (2) implementation outcomes. In this regard, intervention-level activities and implementation-level activities are very highly and positively related in that effective intervention outcomes will necessarily lead to effective implementation outcomes. That is, the right interventions, correctly applied, must lead to the desired implementation outcomes.

Implementation is the most important phase of the project cycle (Association for Project Management 2006; Hoare 1973; Maruapula 2008; Meredith \& Mantel 2012). Successful project implementation will result in a successful project. However, successful project implementation is complex and difficult (Slevin \& Pinto 1987). However, this is not to say that successful project implementation is an impossible feat or a quest for the Holy Grail. The challenge, therefore, is to deploy all efforts to ensure successful implementation, and hence a successful project. Vitally, what is a successful project? Put another way, what are the success criteria for successful project implementation? This subject has excited debate in the project management literature and also spawned a cornucopia of writings on the subject (e.g. see Baker, Murphy \& Fisher 1983; Cleland \& King 1983; Locke 1984; Martin 1976; Sayles \& Chandler 1971). Slevin and Pinto (1987:34) have developed 10 successful project implementation factors as:

- Project mission: initial clarity of goals and general direction.

- Top management support: willingness of top management to provide the necessary resources and authority or power required for project implementation.

- Project schedules and plans: detailed specification of the individual action steps required for project implementation.

- Client consultation: communication and consultation, and active listening, to all affected parties.

- Personnel: recruitment, selection and training of the necessary personnel for the project team.

- Technical tasks: availability of the required technology and expertise to accomplish the specific action steps.

- Client acceptance: the act of 'selling' the final product to its intended users.

- Monitoring and feedback: timely provision of comprehensive control information at each stage in the implementation process.

- Trouble shooting: ability to handle unexpected crises and deviations from the plan.

All things being equal, successful project implementation would ensure project success. At a minimum, a successful project must be implemented as per the Project Management Triangle (also known as Triple Constraint or the Iron Triangle) of 'scope' (quality), 'time' and 'cost/budget'. The Project Management Triangle constitutes key performance indicators (KPIs). However, it is vital to note that although KPIs constitute necessary conditions for project success, they do not constitute sufficient conditions for project success. Therefore, a project manager must cast his or her eyes beyond KPIs. He or she must also consider key success factors (KSFs) (e.g. see Kerzner 2006 on KSFs). Examples of KSFs are scope, schedule, budget, risk, resources and quality (Kerzner 2006).

It has been a well-recognised axiom in project management research that the project implementation process can be greatly facilitated by addressing a variety of project critical success factors (Pinto \& Prescott 1990:305). Pinto and 
Prescott argue that critical factors often fall into two distinct subgroups: (1) those related to initial project planning and (2) those concerned with subsequent tactical operationalisation. Despite guidance in terms of successful project implementation factors, the literature is replete with instances of unsuccessful project implementation in both developed and developing countries. In the main, this results in time and budget (cost) overruns and poor quality products. It is notable that causes of poor project implementation are multifaceted, multidimensional and happen at different levels. These are as follows: (1) the project, (2) project manager and team members, (3) factors related to the organisation and (4) factors related to the external environment. Therefore, it is vital to look at these various aspects of poor project implementation.

Botswana, similarly, suffers from the malaise of poor project implementation. This has been documented in works by, amongst others, Maruapula (2008), Phatshwe (2014), Kaboyakgosi and Sengwaketse (2003), Kaboyakgosi and Marata (2013), Khama (2012) and Mathambo (2014, 2015), midterm reviews of NDPs, consultancy reports and newspaper reports (e.g. BOPA 2000, 2012, 2013, 2015; Lucas 2008; Segaetsho \& Mpuang 2015; Sunday Standard Reporter 2015). Memorably, when delivering the opening address at the 12th National Business Council on 14 October 2012, President Ian Khama (2012) said:

Our policy framework is good, but implementation continues to be a challenge on account of the regulatory framework and rigorous processes. This, I believe, calls for Government to review the existing processes in order to expedite service delivery if we are to succeed in our economic diversification efforts. (Khama 2012:12)

Although there is a universal agreement in Botswana that the country suffers from the malaise of poor project implementation, the Botswana-specific literature is yet to definitively pronounce on the causes. Nonetheless, there have been efforts to document causes of poor project implementation, for example declining public accountability, lack of commitment to reforming the public sector, decline in commitment by state authorities (Kaboyakgosi \& Marata 2013:316) and lack of a culture of professional project management in Botswana (Maruapula 2008). In conclusion, the cumulative effects of poor project implementation are as follows: (1) time and budget (cost overruns) and (2) shoddy projects. Moving forward, there is a demonstrated case for improved public project implementation. This is particularly pertinent in an era characterised by fiscal stress during the NDP 11 period (2017/2018-2022/2023).

\section{Research methodology}

This article is grounded in the intrepretivist research philosophy and used the survey strategy. It adopted the descriptive approach because it primarily sought to observe and describe the state of affairs, the state of public project implementation in Botswana. In terms of data collection, the article used methodological triangulation by using both primary and secondary data collection sources. Primary data collection was in the form of an interview with one senior officer at the Government Implementation Coordination Office (GICO). Very vital to note, 'qualitative research methods differ from quantitative approaches in many important respects, not the least of which is the latter's emphasis on numbers' (Baker \& Edwards 2012:8); therefore, the author chose to conduct one in-depth interview with a senior officer at the GICO. Secondary data sources were multiple and varied: published works (e.g. Kaboyakgosi \& Marata 2013; Kaboyakgosi \& Sengwaketse 2003; Khama 2012; Maruapula 2008; Mathambo 2014, 2015; Phatshwe 2014), midterm reviews of NDPs, consultancy reports and newspaper reports (e.g. BOPA 2000, 2012, 2013, 2015; Lucas 2008; Segaetsho \& Mpuang 2015; Sunday Standard Reporter 2015). Finally, data analysis was in the form of interview (for primary data) and document analyses (for secondary data). The analysis was also used as the basis for policy recommendations.

\section{Institutional framework of public project implementation in Botswana}

Although the formulation of the NDPs predates independence, the first being Transitional National Development produced in 1965 (a year before independence in September 1966), there were no formal arrangements to coordinate project implementation. Even at the time that Botswana was inaugurating a series of public sector reforms such as the Work Improvement Teams movement in 1992, followed by the Performance-based Management System in the late 1990s and cognate tools such as Business Process Reengineering and Balanced Score Card, public project implementation was not accorded the prominence it deserved despite the fact that successful project delivery is critical to the translation of national goals into reality. At the same time, there was concern over poor public project implementation as sufficiently instanced by then President Ketumile Masire, lamenting in mid-1995 that 'there is a growing gap between the establishment of policy and its implementation' and that 'the rapid growth in the formulation of policies have [sic] not been matched by the pace of implementation' (Lucas 2008:10). However, these lamentations were not matched by any policy action through the establishment of public project implementation tools save ad hoc ones that oversaw implementation in a disjointed fashion. With the departure of Masire, Festus Mogae took over on 01 April 2008 during the tail end of NDP 9. He too worried over the issue of poor public project implementation. This actuated him to recall his then vice president, Ian Khama, from an unprecedented sabbatical in early August 2000 so that he could oversee public project implementation. Mogae reasoned that the recall was so that he (Khama) 'could direct and coordinate ministries to ensure efficiency and expeditious implementation of government projects and programmes' (BOPA 2000:1). Mogae also did something unprecedented; he divested the vice president of his ministerial duties (then, he was the Minister of Presidential Affairs and Public 
Administration) so that he could only concentrate on the overseeing of public project implementation. With no performance targets established, there was no tool to judge the performance of the public project implementation czar. However, with the benefit of hindsight, it can be believably argued that nothing significantly changed regarding public projectimplementation. That is, public project implementation was still very problematic.

At the same time, there were moves to improve the institutional architecture of public project implementation as instanced by reforms that saw the merging of then Department of Architecture and Building Services (DABS) and Department of Electrical and Mechanical Services (DEMS). The merging resulted in the creation of the Department of Engineering and Building Services (DBES) on 11 August 2003. DBES has the portfolio responsibility for government building development projects, their associated infrastructure, engineering services and the maintenance of government building, and electrical and mechanical stock (Government of Botswana 2011). Amongst its many divisions is the Project Implementation Division (PID). The division is comprised of 10 units, with each unit assigned a specific portfolio of projects or ministries that it is responsible for. Each unit coordinates a project team made up of consultants and contractors engaged to deliver projects for the relevant government ministry (Government of Botswana 2011). Ever since the creation of the DBES, Botswana experienced a phenomenal growth in the gross domestic product with a corresponding increase in activities including construction projects (Government of Botswana 2011). The growth in the construction industry was largely driven by government projects initiated by ministries even though their implementation was the responsibility of the DBES. Post 2008, there was a slowdown in construction activity. However, the DBES was equally involved in finishing ongoing projects. To enhance operational efficiency, the DBES was structured to meet the systemic problems that were inherent in the former DABS and DEMS (Government of Botswana 2011). The focus has, therefore, been on creating a viable and vibrant Department that is modernised and streamlined to be efficient in service delivery (Government of Botswana 2011). Although no studies have been conducted to assess the efficiency and effectiveness of the DBES in regard to its mandate of project implementation, anecdotal evidence seems to suggest that there have been issues with public project implementation. Epic failures such as National Stadium in Gaborone, Sir Seretse Khama International Airport in Gaborone, Francistown Stadium in the City of Francistown and Morupule B Power Plant in Palapye speak volumes on the public project implementation record of the DBES. Even though the poor record of public project implementation cannot be solely laid at the door of the DBES, the Department must take a disproportionate share of the blame because it is the project manager. To this end, in project management, the project manager must shoulder a disproportionate share of project failures.

In view of the above-mentioned problems that were faced by the DBES and in a bid to coordinate public project implementation, the government established the GICO in May 2007. By late 2008, the government had kick-started the operationalisation of the GICO. When speaking at the signing of a management contract between GICO and Accenture, then director general of the GICO, Moses Lekaukau, stated that setting up the GICO was a 'tall order' (BOPA 2008a:2). Specifically, he said that 'it has been a tall order because the office had to be set up from scratch including the selection and recruitment of professional and support staff' (BOPA 2008a:2). GICO replaced prior arrangements in which project implementation coordination was carried out through the Standing Committee on Projects Implementation (SCOPI) and bilateral meetings between DBES and Government Implementing Agency. Underscoring the central role played by the GICO in public project implementation and budget effectiveness, Lekaukau said that it is now imperative that government policies are implemented through programmes and projects to benefit the society' and that 'the ideal goal of any country is to spend 100 per cent of its annual development budget, and it is GICO's mandate to aid the nation to achieve the ideal' (BOPA2008a:2). GICO was dissolved and subsumed into the National Strategy Office (NSO) in May 2009. As part of further public sector reforms, the Government Implementation Coordination Unit (GISU) was created within the NSO to further improve project implementation in May 2014. Upon further reflection, the government decided to separate strategy and public project implementation functions. The thinking was that 'NSO had to focus on strategy issues and GICO to focus on the monitoring of the implementation of government projects' (Interview, 16 November 2016). This resulted in the decoupling of the GICO from the NSO such that the two are stand-alone entities. The reconstituted GICO has the same mandate that was given to it when it was first established in May 2007. However, it has introduced innovations such as the project management dashboard (PMD) that is shown in Figure 1.

As is deducible from Figure 1, GICO has developed and uses PMDs. It is notable that GICO did not reinvent the wheel because its tool is based on PMDs that are readily available from the Project Management literature (see e.g. Kerzner 2013). A PMD is the central component of project tracking systems and, amongst others, it provides project managers with an overview of a project's progress. It captures data about achievement of milestones and displays the information in a simple format. It has project metrics that are measurable and actionable. It is notable that the PMD in Figure 1 allows GICO to track project management KPIs. These are as follows: (1) Planned Value project KPI (this is the budgeted cost of work scheduled), (2) Actual Cost project KPI (this is the actual cost of work performed) and (3) Earned Value project KPI (this is the budgeted cost of work performed).

GICO has also developed service score cards. To provide a brief explanation, 'the Community Score Card (CSC) is a twoway and ongoing participatory tool for assessment, planning, monitoring and evaluation of services' (CARE [Malawi] 2013:5). The CSC brings together the demand side ('service 


\begin{tabular}{|c|c|c|c|c|c|c|c|c|c|c|c|c|c|c|c|}
\hline \multirow[b]{2}{*}{ 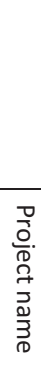 } & \multirow[b]{2}{*}{ 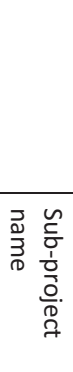 } & \multirow[b]{2}{*}{ 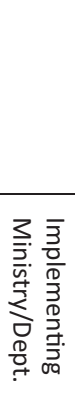 } & \multirow[b]{2}{*}{ 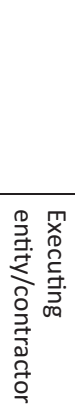 } & \multirow[b]{2}{*}{ 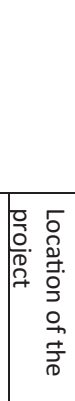 } & \multicolumn{2}{|c|}{ Budget } & \multicolumn{5}{|c|}{ Timelines } & \multicolumn{2}{|c|}{$\begin{array}{l}\text { Progress } \\
(\% \\
\text { completed })\end{array}$} & \multirow[t]{2}{*}{$\begin{array}{l}\text { Reasons if } \\
\text { progress below } \\
\text { target }\end{array}$} & \multirow[t]{2}{*}{$\begin{array}{l}\text { Recommendations } \\
\text { and proposed } \\
\text { actions }\end{array}$} \\
\hline & & & & & 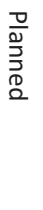 & 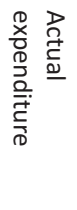 & 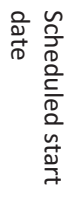 & 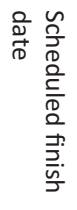 & 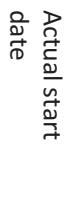 & 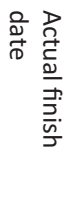 & 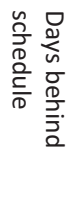 & 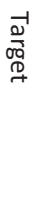 & 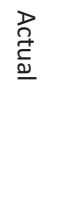 & & \\
\hline & & & & & & & & & & & & & & & \\
\hline
\end{tabular}

Source: GICO office 2016

FIGURE 1: GICO's project management dashboard.

TABLE 1: Sample combined service score card.

\begin{tabular}{|c|c|}
\hline Service $^{a}$ & Scoring $(0 \%-100 \%)^{b}$ \\
\hline Adequacy and condition of classrooms & 50 \\
\hline Availability of electricity & 60 \\
\hline Vehicle registration & 70 \\
\hline Issuance of drivers' licence & 55 \\
\hline Land allocation & 78 \\
\hline Transport availability & 75 \\
\hline Refuse collection & 20 \\
\hline
\end{tabular}

user') and the supply side ('service provider') of a particular service or programme to jointly analyse issues underlying service delivery problems and find a common and shared way of addressing those issues (CARE [Malawi] 2013:5). Amongst others, the score card enhances participation, accountability and transparency between service users, providers and decision-makers (CARE [Malawi] 2013:5). Through the tool, the community scores the implementation of services and projects (see Table 1).

The scores are displayed in bar charts as shown in Figure 2, and the information is shared with service providers so that they can take corrective action.

Finally, key service providers, being ministries, are rated on their performance on the following core mandate areas: implementation of policies, programmes and projects, Business and Economic Advisory Council ${ }^{1}$ action items, performance of parastatals, committee of supply, maintenance of facilities, service delivery, 10-point agenda ${ }^{2}$, youth empowerment and dipitso. ${ }^{3}$ The ministries are ranked on a three-point scale of 'Very Good or Good' (colourcoded green), 'Satisfactory' (colour-coded yellow) and 'Unsatisfactory' (colour-coded red) as shown in Table 2.

1.The Business and Economic Advisory Council (BEAC) was established in August 2005 to address the challenge of lack of economic diversification in Botswana.

2.The 10-point agenda was introduced as a government service pledge with clearly laid out service standards that were developed to improve the quality of service and productivity level within the public service.

3.These are public opinion-gathering events.
Currently, there are 18 ministries, some examples being (1) Presidential Affairs, Governance and Public Administration, (2) Defence, Justice and Security, (3) Agricultural Development and Food Security, (4) Infrastructure and Housing Development, (5) Ministry of Basic Education, (6) Environment, Natural Resources Conservation and Tourism and (7) Finance and Economic Development, which are appraised. These annual appraisals are conducted by the GICO and remitted to the Office of the President for dialogue with the ministries.

In addition to the establishment of the GICO, the Khama administration (01 April 2008-present) came up with other public project implementation-enhancing initiatives. Chief among them was the 5th D (Delivery). To provide a context, President Ian Khama on 01 April 2008 introduced 4 Ds as Democracy, Dignity, Discipline and Development (Khama 2008). Over time, and informed by his interaction with the nation through kgotla meetings (public meetings), it became apparent to Khama that public service delivery was problematic. This actuated to him to introduce the 5th D (Delivery) to his 4-D roadmap. Immediately after the Botswana Democratic Party (BDP) won the general election in 2009, he introduced the 5th D on 18 October 18, saying:

I have already started my job as the President. I am adding another ' $\mathrm{D}$ ' to the Four Ds I introduced when I took over last year. I am introducing the Fifth ' $\mathrm{D}$ ' for Delivery. You are going to see us deliver, you shall be the witnesses. (Gaotlhobogwe 2009:1)

Admittedly, not enough empirical work has been conducted to assess the efficacy of various initiatives such as the GICO and 5th D. However, anecdotal evidence suggests that, overall, public project implementation is problematic. Next, the article discusses stories from the field that confirm that there are challenges in public project implementation.

\section{Stories from the field on public project implementation}

Apart from documented work by Maruapula (2008), Phatshwe (2014), Kaboyakgosi and Sengwaketse (2003) and Kaboyakgosi and Marata (2013), amongst others, on problems of public project implementation, stories from 


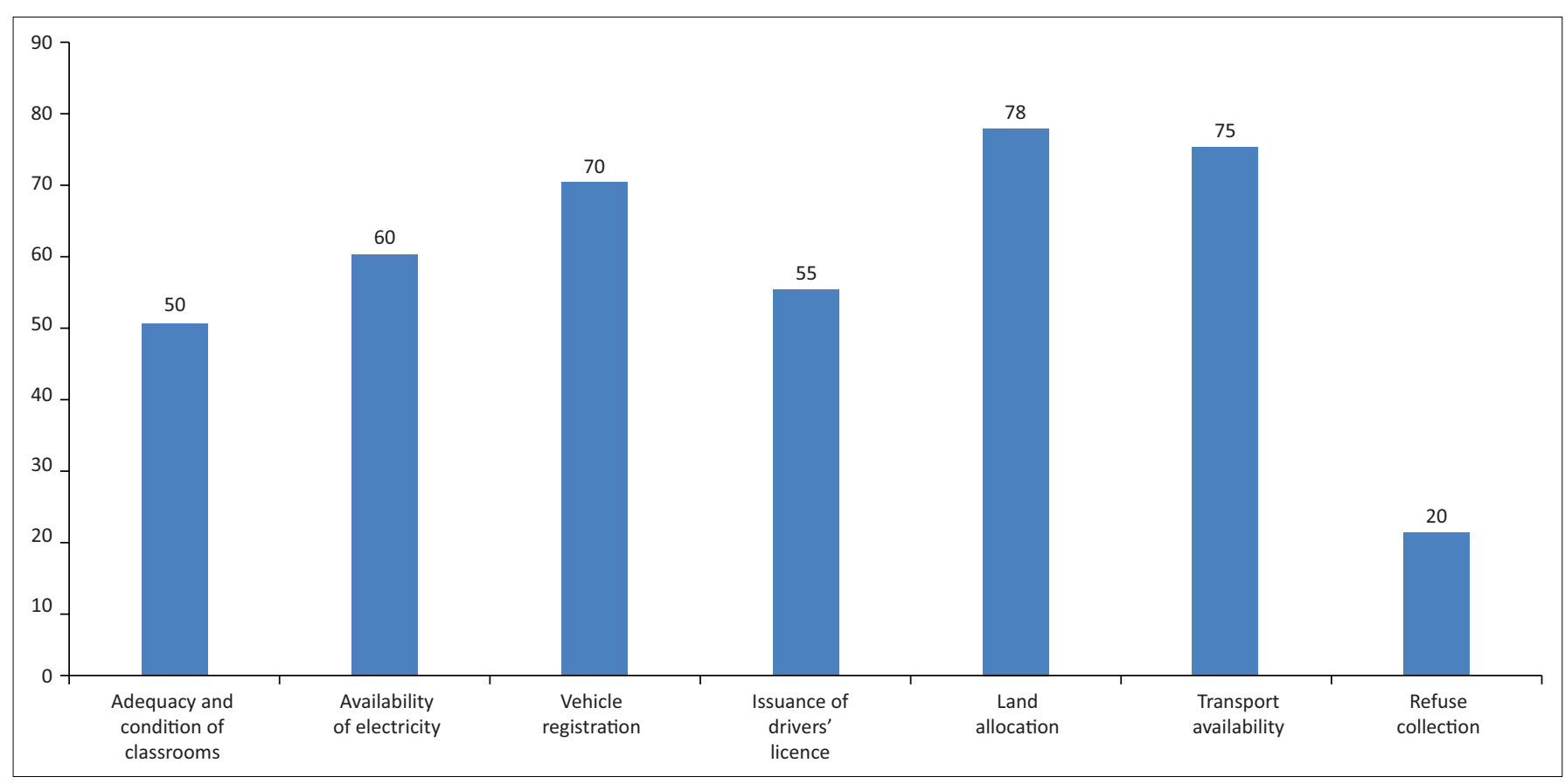

Source: GICO Office (2016)

Figure 2: Sample combined service score card.

TABLE 2: Performance on core mandate areas.

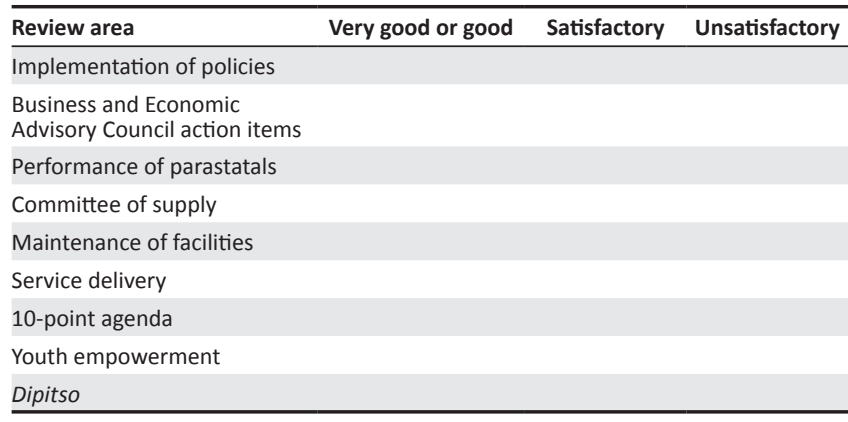

Source: GICO office 2016

the field provide an insight into the problem as is illustrated next. The issue was thrust to national prominence during the 12th National Business Conference (NBC) that was held in Francistown from 14 to 17 October 2012. The overarching objective of the 12th NBC was to discuss the issue of implementation as sufficiently deducible from the theme Interrogating Implementation - why is it a challenge? Leaders and visionaries from the government and private sector shared and exchanged ideas on a variety of themes. These included some of the following: Infrastructure Development, Education and Skills Development, Land Use for Business, Privatisation, Economic Diversification, Youth Unemployment and Diamond Trading Company International's relocation from London to Botswana. The NBC was attended by President Ian Khama, amongst others. President Khama talked of the need to enhance project implementation when officially opening the 12th NBC. To illustrate, he said that despite a good policy framework, project implementation continued to be a challenge because of the regulatory framework and rigorous processes (BOPA 2012:1). Very importantly, he told the participants that the problem of problematic project implementation demanded interventions from all stakeholders. He thus said:

it is a hallmark of my administration to listen to a range of views, whether conventional or unconventional, from within the government, from the private sector, from civil society and from outside the country. (BOPA 2012:1)

He also implored the private sector to improve its work ethic so that it successfully delivered government projects like it did with respect to private sector projects. Finally, he assured the participants that input from fora such as the NBC was being factored into the public policymaking process. In a confirmatory vein, he stated that resolutions emanating from the previous NBCs had been implemented, thereby 'making Botswana much better' (BOPA 2012:1).

Politicians, eschewing partisan politics, often express misgivings about poor public project implementation. To illustrate, when debating the 2013/2014 Budget Speech in Parliament, the then Member of Parliament for the Nkange constituency, Edwin Batshu, warned government to act swiftly to remedy the problem of slow implementation of projects facing the public sector (BOPA 2013). He expressed the concern that delays were costly and thus delayed developments. Batshu gave the example of the Morupule $\mathrm{B}$ power project 'as one of the major disappointments concerning implementation of government projects' (BOPA 2013). He lamented that the construction of the power station, which was envisaged to increase production of electricity in Botswana, did not meet the planned completion time (BOPA 2013). ${ }^{4}$ In a related vein, cabinet ministers have also expressed worry on poor public project implementation.

4. Even though the project was finished some years beyond schedule, it is fraught with problems such that the government took a decision to sell the loss-making power plant to an independent power producer. 
In this regard, an excerpt from then Minister of Finance and Development Planning, Kenneth Mathambo, when delivering the 2015/2016 Budget Speech on 02 February 2015, is enlightening and very sobering. Addressing issues of poor public project implementation, he said:

Madam Speaker, project implementation remains one of the challenges facing the Government. During NDP 10, the development budget has been underspent by an average of 17.3 percent for the years 2011/2012 through 2013/2014, due to delayed project implementation. Even where projects are finally delivered, they are usually characterised by cost overruns and questionable quality. (Mathambo 2015:6)

It is deducible from the above-mentioned selected field stories that there are serious challenges surrounding public project implementation in Botswana. In a related vein, assessments by third parties (i.e. those external to the government) are not very encouraging for they echo the same message. To illustrate, in late January 2015, Innolead Consulting co-hosted a seminar with Oracle Primavera at the Gaborone International Convention Centre. What came out during the discussions strongly suggests that governmental operational processes and systems are not well primed for project management (Sunday Standard Reporter 2015). It is notable that although the government spends huge sums of money on project management training, the outcome is not bearing any fruit. For instance, it was stated that 'the current situation doesn't allow people to use skills they have learnt' and that 'some of the engineers who receive project management ... are not given responsibilities in line with this training but resume their normal duties when they get back to the office' (Sunday Standard Reporter 2015).

It can be concluded from the preceding brief survey that efforts to enhance public project implementation have not borne commendable fruit. Therefore, as stated by then Minister of Finance and Development Planning when he delivered the 2015/2016 Budget Speech on 02 February 2015. 'during NDP 10, the development budget has been underspent by an average of 17.3 percent for the years 2011/2012 through 2013/2014, due to delayed project implementation' (Mathambo 2015:6); this is a cause for worry. In a related vein, a midterm review of NDP 10 (Ministry of Finance and Development Planning 2012) shows that there are public project implementation challenges. In specific reference to the public buildings sector, the report alluded that 'poor project management due to insufficient planning and skills capacity deficiency reduce efficiency of project delivery' (Ministry of Finance and Development Planning 2012:37). The results were the following: project cost overruns, frequent scope changes, conflicts on sites and late completion of projects (Ministry of Finance and Development Planning 2012:37). In addition, some projects that were lined up for implementation during the NDP 10 period were not implemented. The result is that these projects, if still needed, will be rolled over to NDP 11 which commenced operations on 01 April 2017. It is notable that the NDP 11 period, 2017/2018-2022/2023, presents serious challenges, the most being a constrained fiscal envelope. The 2017/2018 Budget
Strategy Paper, the precursor to the 2017/2018 budget, forecasts budget deficits for the 2016/2017, 2017/2018, 2018/2019 and 2019/2020 financial years mainly because of declining diamond revenues (Ministry of Finance and Development Planning 2016). This, ineluctably, means that there will be limited revenues to fund NDP 11 development projects. In summary, it means that there is a need to revamp the architecture of public project implementation in Botswana.

\section{Suggestions for improving public project implementation during NDP 11}

Admittedly, enhancing the architecture of public project implementation in Botswana needs a multifaceted, multilayered and multistakeholder approach. That is, the enterprise must be approached from many and varied angles as briefly recommended below.

Professional Project Management: as variously documented in the literature (e.g. see Association for Project Management 2006; Hoare 1973; Maruapula 2008; Meredith \& Mantel 2012), implementation is the most important phase of the project cycle. Therefore, utmost attention must be paid to the implementation phase of the project cycle as counselled by Thato Raphaka, then Permanent Secretary in the Ministry of Local Government, when launching the draft NDP 10 in October 2008. He counselled:

Let me caution you that we may have good policies, programmes and strategies but if our capacity to implement them, both within government and in the economy as a whole is wanting, then we may not easily reach our noble intentions. (BOPA 2008b:1)

Amongst others, successful public project implementation is predicated on the application of the science of professional project management, complete with trained (career) project managers. Two problems are evident in the public sector: (1) lack of an approach to professional project management and (2) preponderant use of accidental project managers. Project management is not accidental; it is something that is purposeful. Therefore, there is a need to cultivate a culture of professional project management in the public sector. That is, the government cannot practise project management by accident. In a related vein, there is a tendency to appoint nonproject managers as project managers. In summary, these are engineers and senior public servants who just happen to be occupying a certain managerial (or senior) position.

Without detracting from the professional training of either engineers or senior public servants, this cadre of personnel is trained in its respective field of either engineering or public management. So, on a balance of probabilities, they could be seasoned engineers or public managers. However, this is as far as their professional competency goes; they cannot be project managers (unless as accidental project managers). In fact, in a field trip undertaken by the author with his Project Management class in September 2015, one of the project officers decried the practice of appointing non-project 
managers as project managers. He told the author that 'the trouble is that some of us are not trained as project managers but we are deployed as project managers' (Interview, 15 September 2015). This practice must stop.

Increased responsibility for performance: in the era of New Public Management, public managers are, on the one hand, given a wide berth of discretion to run their departments like entrepreneurial entities, amongst others. On the other hand, they are expected to account more for their performance (i.e. results or non-results). While the law, for example, Public Finance Management Act (2011), provides for sanctions for incidents in which the government needlessly loses money through the actions of public officials, this is done in the breach than in the observance. In the end, the government loses billions of Pula ${ }^{5}$ because of, amongst others, negligence, but only a few are held to account for these losses. Hence, the time is nigh for public officials to be held accountable for their performance with respect to project implementation.

Resourcing and capacitating of DBES: as the department responsible for public project implementation, it is vital that the DBES is adequately resourced and capacitated despite challenges of fiscal strictures post 2008. It became apparent from discussions with some DBES staff during a field trip undertaken by the author with his Project Management class in September 2015 that the DBES is beset with resource and capacity constraints (particularly, financial resources and trained project managers and project officers).

Transformation of GICO into a delivery unit: it is apparent that GICO has a very extensive mandate - to coordinate the implementation of programmes and projects across government to ensure efficient service delivery. To do so, it must be adequately resourced and capacitated. Post 2008, like other government departments, GICO has had to contend with resource and capacity problems (Interview, 16 November 2016). Beyond resourcing and capacitating GICO, there is a need to widen the mandate of GICO and transform it into a Public Service Delivery Unit. In this regard, several governments around the world have established Public Service Delivery Units. Examples are UK (Prime Minister Tony Blair created the Prime Minister's Delivery Unit in June 2001 - this was abolished in 2010), India (the Cabinet Secretariat for Performance Management), Indonesia (Presidential Unit), Malaysia (Performance Management Delivery Unit) and South Africa (Delivery Unit). These units are 'generally tasked with the mandate to drive performance improvements in critical service delivery areas' and may be in addition required to implement 'broader reforms to improve performance, such as restructuring civil service terms, performance-based contracts or delegation of financial management' (World Bank 2010:2). Thus, Botswana can peerlearn and benchmark from these said case studies. It does not need to apply the lessons wholesale; it can customise them by paying heed to Botswana-specific circumstances.

5.At the time of writing this article (6 July 2017), one Botswana Pula (BWP) $=0.096$ US Dollar.

\section{Conclusion}

The government has an obligation to provide goods that the market either cannot produce (e.g. national defence) or produces in insufficient quantities (e.g. education and health services). Unfortunately, governments have to deal with everlasting issues of resource scarcity. In addition, as custodians of national resources, governments must unremittingly pursue prudent financial management. To address the twin issues of resource scarcity and prudent financial management, particularly the former, the government of Botswana engages in national development planning. Planning is actualised through NDPs that are produced every six years. The NDPs are mere intentions that can only have a meaning if they are translated into goods and services, such as schools and hospitals, to improve the lives of the Batswana. Therefore, project implementation is key to this success. However, Botswana has a chequered history of project implementation as documented in the literature. A review of the NDPs, particularly NDP 10, shows that public project implementation is very problematic. NDP 10 came to an end on 31 March 2017 and parliament approved a draft of NDP 11, the implementation of which began on 01 April 2017. Given a constrained revenue envelope post 2008, it is imperative that things should be done differently. Thus, the case for improved public project implementation should be apparent to all. Amongst others, this calls for the adoption of professional public project implementation and increased responsibility for results and non-results by public managers. Doing so will ensure that NDPs are actualised and, therefore, translated into tangibles such as goods and services.

\section{Acknowledgements Competing interests}

The author declares that he has no financial or personal relationships which may have inappropriately influenced him in writing this article.

\section{References}

Association for Project Management, 2006, APM Body of Knowledge, Association for Project Management, Buckinghamshire.

Baker, B.N., Murphy, D.C. \& Fisher, D., 1983, 'Factors affecting project success', in D.I. Cleland \& W.R. King (eds.), Project management handbook, pp. 669-685, Van Nostrand, New York.

Baker, S.E. \& Edwards, R., 2012, How many qualitative interviews is enough? Expert voices and early career reflections on sampling and cases in qualitative research, National Centre for Research Methods, Southampton, England.

Botswana Press Agency (BOPA), 2000, 'Khama's leave cut short', Daily News, 7 August, p. 1.

Botswana Press Agency (BOPA), 2008a, 'Govt establishes coordination office', Daily News, 22 December, p. 2.

Botswana Press Agency (BOPA), 2008b, 'NDP 10 unique, aligned to Vision 2016' Raphaka', Daily News, 29 October, p. 1.

Botswana Press Agency (BOPA), 2012, 'Diversification drive on track', Daily News, 16 October, p. 1.

Botswana Press Agency (BOPA), 2013, 'MP decries slow project implementation', Daily News, 14 February, p. 1.

Botswana Press Agency (BOPA), 2015, 'Corruption, poor execution remain challenge', Daily News, 29 March, p. 1 .

CARE [Malawi], 2013, The Community Score Card (CSC): A generic guide for implementing CARE'S CSC process to improve quality of services, CARE, Lilongwe. 
Cleland, D.I. \& King, W.R., 1983, Systems analysis and project management, McGrawHill, New York.

Denton, J.A., 1990, Society and the official world; a reintroduction to sociology, General Hall, Dix Hills, NY.

Fixsen, D.L., Naoom, S.F., Blase, K.A., Friedman, R.M. \& Wallace, F., 2005, Implementation research: $A$ synthesis of the literature, University of South Florida, Tampa, FL.

Gaotlhobogwe, M., 2009, 'Ebullient Khama tells victory rally of fifth “D”', Mmegi, 19 October, p. 1.

Government of Botswana, 2011, Department of Building and Engineering Service, viewed 14 November 2016, from http://www.gov.bw/en/Ministries--Authorities/
Ministries/MIST-Events/Departments/Department-of-Building-and-EngineeringServices-DBES1/

Hoare, H.R., 1973, Project management: Using network analysis, McGraw Hill, New York.

Kaboyakgosi, G. \& Marata, K.P., 2013, 'An analysis of Botswana's implementation challenges', PULA: Botswana Journal of African Studies 27(2), 309-324.

Kaboyakgosi, G. \& Sengwaketse, M., 2003, Construction and related services in Botswana, viewed 18 October 2015, from http://www.tips.org.za/files/694.pdf.

Kerzner, H.R., 2006, Project management: A systems approach to planning, scheduling, and controlling, 11th edn., Wiley, New York.

Kerzner, H.R., 2013, Project management metrics, KPIs, and dashboards: A guide to measuring and monitoring project performance, 2 nd edn., Wiley, New York.

Khama, I., 2008, Inauguration address by His Excellency Lieutenant General Seretse Khama, Government Printer, Gaborone.

Khama, I., 2012, Opening address at the 12th National Business Council, 14-17 October 2012, Adansonia Hotel, Francistown, Botswana.

Locke, D., 1984, Project management, St. Martins, New York.

Lucas, T., 2008, 'Botswana's implementation problematic: A case for a comprehensive audit', Mmegi, 21 February, p. 10.

Martin, C.C., 1976, Project management, AMACOM, New York.

Maruapula, O., 2008, Facilitative project management in Botswana; context interrogation beyond construction, Pentagon, Gaborone.

Mathambo, K., 2014, 2014/15 budget speech, Government Printing and Publishing Services, Gaborone.
Mathambo, K., 2015, 2015/16 budget speech, Government Printing and Publishing Services, Gaborone.

Mathambo, K., 2017, 2017/18 budget speech, Government Printing and Publishing Services, Gaborone.

Meredith, J.R. \& Mantel, S.J., 2012, Project management; a managerial project, 8th edn., Wiley, Singapore.

Ministry of Finance and Development Planning, 1975, National Development Plan 3 (1970-5), Government Printing and Publishing Services, Gaborone.

Ministry of Finance and Development Planning, 2012, Midterm review of NDP 10 Government Printing and Publishing, Gaborone.

Ministry of Finance and Development Planning, 2016, 2017/18 Budget Strategy Paper, Government Printing and Publishing, Gaborone.

National Implementation Research Network, 2014, Implementation defined viewed 12 March 2015, from http://nirn.fpg.unc.edu/learn-implementation/ implementation-defined.

Phatshwe, J.P.D., 2014, 'Silo based projects: A case for Botswana National Productivity Centre', MSc dissertation, Cranefield College of Project and Programme Management, Pretoria.

Pinto, J.K. \& Prescot, J.K., 1990, 'Planning and tactical factors in the project implementation process', Journal of Management Studies 27(3), 305-327. https://doi.org/10.1111/j.1467-6486.1990.tb00249.x

Project Management Institute, 2013, A guide to Project Management Body of Knowledge (PMBOK), 5th edn., Project Management Institute, Newtown Square, PA.

Sayles, L.R. \& Chandler, M.K., 1971, Managing large systems, Harper \& Row, New York.

Segaetsho, T. \& Mpuang, L., 2015, 'Molepolole bus rank project; the plot thickens', The Botswana Gazette, 5-11 August, p. 2.

Slevin, D.P. \& Pinto, J.K., 1987, 'Balancing strategy and tactics in project implementation', Sloan Management Review 3(3), 33-41.

Sunday Standard Reporter, 2015, 'Minister acknowledges project implementation challenges', Sunday Standard, 9 February, p. 1.

World Bank, 2010, Driving performance through Center of Government delivery units, viewed 30 November 2016, from http://siteresources.worldbank.org/ EXTGOVANTICORR/Resources/3035863-1285601351606/NovemberGetNote.pdf. 